\title{
Kestabilan Fenotip Tanaman Labu Susu (Cucurbita moschata (Duchesne) Poir "Butternut") Hasil Budidaya di Sleman D.I Yogyakarta
}

\author{
HETTY NOPIANASANTI ${ }^{1}$, BUDI SETIADI DARYONO ${ }^{1}$ \\ ${ }^{1}$ Laboratorium Genetika dan Pemuliaan, Fakultas Biologi, Universitas Gadjah Mada \\ J1. Teknika Selatan, Sekip Utara, Sleman, Yogyakarta. 55281 \\ Email: bs_daryono@ugm.ac.id \\ Received 24 April 2018; Received in revised form 3 May 2018; \\ Accepted 31 July 2018; Available online 26 November 2018
}

\begin{abstract}
Butternut pumpkin (Cucurbita moschata 'Butternut') is a horticultural commodity with great potential to be developed as food and medicine. Nutrients and unique shape cause butternut pumpkin to be popular. To supply of butternut pumpkin, required an increase in production which has superior and stable characters. This research aims to determine the stability phenotypic characters of butternut pumpkin in Sleman, Yogyakarta using quantitative data analysis of variance (One Way ANOVA) and qualitative analysis through descriptive phenotype. Based on the results, butternut pumpkin have a uniform phenotype characters but unstable in fruit's shape and size of plant. Butternut pumpkin plants have 3 different shapes of pear or paprika form including dumbbell shape and gooseneck (pyriform), crispy texture, pale yellow (RHS greyed grange group 65) peel of fruit, strong orange (RHS orange group 24) flesh of fruit, $3-5^{\circ}$ brix level of sweetness, long shelf life, and short harvest age (70-90 HST). The cultivated butternut pumpkin in PIAT UGM farmland has greater productivity of $3.1 \pm 0.99 \mathrm{~kg} / \mathrm{plant}$.
\end{abstract}

Keywords: Cucurbita moschata 'Butternut', phenotypic characters, productivity

\section{INTISARI}

Labu susu (Cucurbita moschata 'Butternut') merupakan komoditas hortikultura yang berpotensi besar untuk dikembangkan sebagai bahan pangan dan obat. Kandungan nutrisi dan bentuk yang unik menyebabkan tanaman ini digemari oleh masyarakat. Diperlukan peningkatan hasil produksi labu susu yang unggul melalui pemuliaan tanaman untuk memenuhi kebutuhan yang terus meningkat. Tujuan penelitian ini adalah untuk mengetahui kestabilan fenotip tanaman labu susu yang dibudidayakan di Sleman, Yogyakarta menggunakan analisis data kuantitatif One Way ANOVA dan analisis kualitatif melalui deskriptif fenotip. Berdasarkan hasil yang diperoleh tanaman labu su su memiliki karakter fenotip yang seragam tetapi belum stabil dalam bentuk buah dan ukuran. Labu susu memiliki 3 bentuk yang berbeda yaitu bentuk buah pir atau paprika yang termasuk bentuk dumbbell dan bentuk leher angsa (pyriform), tekstur renyah, kulit buah berwarna pale yellow (RHS greyed orange group 65), warna daging buah strong orange (RHS orange group 24), tingkat kemanisan $3-5^{\circ}$ brix, daya simpan lama, dan umur panen yang singkat (70-90 HST). Labu susu hasil budidaya di lahan PIAT UGM memiliki produktivitas yang lebih besar yaitu 3,1 $\pm 0,99 \mathrm{~kg} / \mathrm{tanaman}$.

Kata Kunci: Cucurbita moschata 'Butternut', karakter fenotip, produktivitas

\section{PENDAHULUAN}

Indonesia merupakan salah satu negara agraris yang memiliki biodiversitas tinggi, termasuk tanaman labu atau waluh yang memiliki potensi besar untuk dikembangkan sebagai sumber bahan pangan. Genus Cucurbita dari familia Cucurbitaceae ini merupakan tanaman tropis dan sub tropis yang terdiri dari 27 spesies (Hazra et al., 2007), mencakup lima spesies domestikasi dengan beberapa kultivar yaitu Cucurbita pepo L. (Summer squash dan Zucchini), Cucurbita maxima Duchesne (Pumpkin), Cucurbita moschata Duchesne (Butternut), Cucurbita argyrosperma Huber (C. mixta Pang.) (Cushaw) dan Cucurbita ficifolia Bouché (Inan et al., 2012; Šiško et al., 2003). Diperkirakan bahwa Cucurbita moschata dan Cucurbita ficifolia berasal dari Asia. Namun, sekarang terbukti bahwa kedua spesies tersebut domestikasi di Amerika Latin meskipun masih belum jelas presisi daerahnya (Purnomo et al., 2015). Meksiko Tengah merupakan pusat daerah asal Cucurbita moschata (Paris and Brown, 2005) dan telah dibudidayakan lebih dari 5.000 sampai 6.000 tahun SM (Bisognin, 2002; Ferriol et al., 2004). Secara sitogenetika, beberapa spesies 
genus Cucurbita memiliki jumlah kromosom sebanyak 20 pasang $(2 n=40)$ dan memiliki beragam kultivar berdasarkan gen mitokondria. Klasifikasi intraspesies Cucurbita moschata secara morfologi didasarkan pada karakter buah dan warna daging buah (Purnomo et al., 2015).

Labu susu (Cucurbita moschata 'Butternut') memiliki karakteristik berupa terna annual, batang herbaceous berbentuk bulat atau bersegi lima tumpul yang dilengkapi sulur berpilin. Bunga berbentuk lonceng (campanulatus), bersifat aktinomorf atau beraturan (regularis), dan terdapat bunga jantan dan bunga hemafrodit pada satu individu. Labu susu atau butternut pumpkin memiliki bentuk buah seperti gitar (dumbbell) dengan berat sekitar 2-5 kg dan dapat dipanen pada umur 3-4 bulan (Hendrasty, 2003; Tedianto, 2012; Wu et al., 2011). Daya simpan dapat mencapai 6 bulan atau lebih dengan rentang suhu paling baik $10-16^{\circ} \mathrm{C}$ dan kelembapan 70\% (Babadoost and Zitter, 2009; Bisognin, 2002).

Labu susu memiliki nilai gizi yang baik bagi tubuh manusia (Riaz et al., 2015). Buahnya mengandung nutrisi dan senyawa bioaktif seperti fenolat, flavonoid, vitamin (termasuk vitamin $\beta$-karoten, vitamin $\mathrm{A}$, vitamin B2, $\alpha$-tokoferol, vitamin $\mathrm{C}$, dan vitamin E) (Suwanto dkk., 2015), polisakarida, protein, asam amino esensial, karotenoid, antioksidan, dan mineral. Kandungan gizi pada buah labu dapat dijadikan makanan alternatif pengganti beras. Tanaman labu dimanfaatkan masyarakat sebagai bubur bayi, sayuran, sumber pakan ternak, pembuatan kuaci, serta obat tradisional sebagai anti diabetes, anti hipertensi, anti tumor, imunomodulasi, anti bakteri, obat cacing pita, dan bahan penawar racun binatang berbisa (Muzzaffar et al., 2016; Suwanto dkk., 2015).

Upaya peningkatan produktivitas dan kualitas labu terus dilakukan melalui pemuliaan tanaman (Human dkk., 2016). Pemuliaan tanaman merupakan kegiatan untuk mengubah susunan genetik tanaman secara tetap (baka) sehingga memiliki sifat atau penampilan sesuai dengan tujuan untuk memperbaiki karakter tanaman. Pemuliaan tanaman umumnya mencakup tindakan introduksi, seleksi, hibridisasi/persilangan, mutasi, dan bioteknologi (Daryono dan Maryanto, 2017). Dalam program pemuliaan tanaman secara konvensional biasanya seleksi terhadap karakter-karakter yang menjadi target dilakukan atas dasar seleksi fenotip/morfologi, baik secara individu maupun populasi tanaman. Penentuan karakteristik merupakan hal yang krusial dalam deskripsi tanaman. Karakteristik yang paling umum digunakan adalah sifat morfologi dan fisiologi, seperti bentuk batang, bentuk daun, ketahanan terhadap penyakit, dan lain-lain.

Berdasarkan hal tersebut, maka penelitian ini bertujuan mengetahui kestabilan fenotip tanaman labu susu hasil budidaya di Sleman, Yogyakarta. Penelitian diharapkan dapat memberikan informasi dan gambaran tentang variabilitas fenotip tanaman labu susu dalam rangka pemilihan tanaman induk untuk mendapatkan bibit yang berkualitas.

\section{METODE}

Penelitian ini dilaksanakan di Pusat Inovasi dan Agroteknologi Universitas Gadjah Mada (PIAT UGM) Berbah dan screen house Jamusan, Sleman, Yogyakarta.

Persiapan Sebelum Tanam. Sebelum dilakukan penanaman labu susu di screen house dan lahan perlu dilakukan penggemburan tanah, pembuatan bedengan, pemupukan, dan pengairan.

Pengecambahan Benih dan Penanaman. Benih labu susu disemai di ruang hangat dengan nampan yang diberi pasir, kain, air, dan lampu 10 watt untuk pengaturan suhu. Tahap inkubasi dilakukan selama 4 hari di bawah sinar lampu. Kecambah yang mulai tumbuh, satu per satu dipindahkan ke dalam polybag yang sudah diberi celah. Kemudian kecambah yang berumur 1 minggu dipindahkan untuk ditanam di lahan. Selain dengan cara pengecambahan, benih labu susu juga bisa langsung di tanam di tanah.

Perawatan, Pemeliharaan dan Pemanenan. Tanaman labu susu yang ditanam di screen house disiram setiap 3 hari sedangkan tanaman labu yang ditanam di lahan, pengairan dilakukan sekali ketika awal 
penanaman. Pada proses penanaman dibarengi dengan penambahan kapur untuk menstabilkan $\mathrm{pH}$ tanah. Pemupukan dan pemberian pestisida dilakukan dua kali per bulan pada masa vegetatif. Tanaman labu susu yang berumur 3 minggu diberikan tiang penyangga. Dilakukan pemotongan cabang batang atau daun pada tanaman labu yang terserang penyakit dan hama. Setiap 3 hari sekali batang yang tumbuh dililitkan pada bambu penyangga agar tanaman labu susu menjalar vertikal dan beberapa cabang yang dekat dengan tanah dipangkas agar pertumbuhan tidak menjalar ke samping. Panen dilakukan apabila telah menunjukkan ciri-ciri seperti warna kulit buah dan tangkai buah cokelat merata, muncul aroma buah labu yang khas, dan apabila diketuk akan terdengar bunyi nyaring. Setelah panen selanjutnya diambil benihnya untuk ditanam kembali.

Pengamatan Uji Kestabilan Karakter Fenotip. Pengamatan dilakukan pada individu tanaman setiap generasi. Karakter yang diamati terdiri dari karakter kualitatif yang menunjukkan morfologi suatu tanaman dan karakter kuantitatif yang menunjukkan sifat agronomis suatu tanaman. Pengamatan karakter morfologis meliputi tipe pertumbuhan, bentuk daun, bentuk batang, bentuk akar, bentuk bunga, bentuk biji, bentuk buah (bentuk buah diamati dari buah hasil panen menggunakan panduan IBPGR), warna buah, batang, akar, bunga, biji, dan daun (diamati menggunakan RHS Colour Chart), rasa buah (buah yang telah dipanen dan siap dikonsumsi, diambil daging bagian dasar dan ujung menggunakan hand refractometer Atago), permukaan buah. Karakter agronomis meliputi umur berbunga (pengamatan dilakukan pada jumlah hari setelah tanam pada saat sudah berbunga 80\%), umur panen, tinggi tanaman, panjang buah, diameter buah, berat buah (dilakukan penimbangan bobot per buah dari buah hasil panen dengan jumlah 10 sampel setiap generasi, selanjutnya dibuat ratarata), tebal kulit buah, tebal daging buah, jumlah buah per tanaman, dan jumlah biji per buah (jumlah biji viable pada satu buah labu susu).

Analisis Data. Analisis karakter fenotip secara kuantitatif menggunakan analisis sidik ragam (One Way ANOVA) dengan Rancangan Acak Kelompok (RAK) dengan menghitung kisaran, rerata, ragam, simpangan baku, dan koefisien keragaman fenotip sedangkan analisis karakter fenotip secara kualitatif dilakukan dengan metode deskriptif kemudian diskoring secara multiple (Ramadhani dkk., 2013).

\section{HASIL}

Tiga puluh tanaman labu susu (C. moschata 'Butternut) dikoleksi dari hasil budidaya di screen house PIAT UGM, lahan PIAT UGM, dan screen house Jamusan, Sleman, Yogyakarta. Variabilitas genetik labu susu berdasarkan karakter morfologi terlihat pada daun, bunga, buah, biji (Gambar 2) serta bentuk buah yang berbeda di setiap lokasi budidaya.

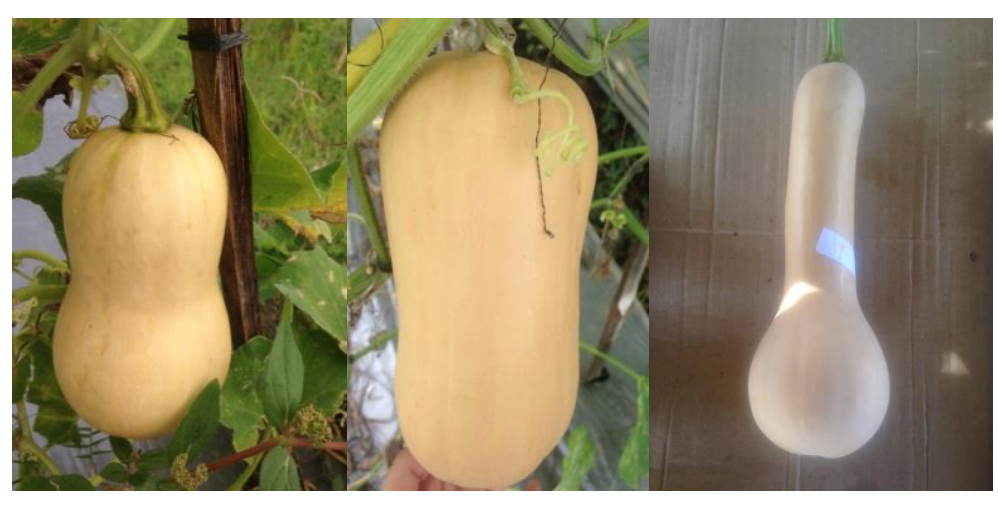

A

B

C

Gambar 1. Karakter bentuk buah labu susu: A. bentuk buah pir (dumbbell), B. bentuk paprika (dumbbell), dan C. bentuk leher angsa (pyriform) 


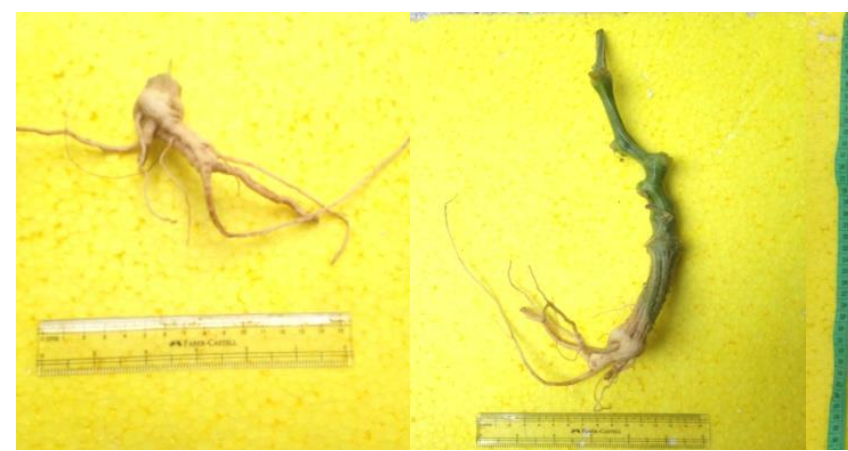

A

B

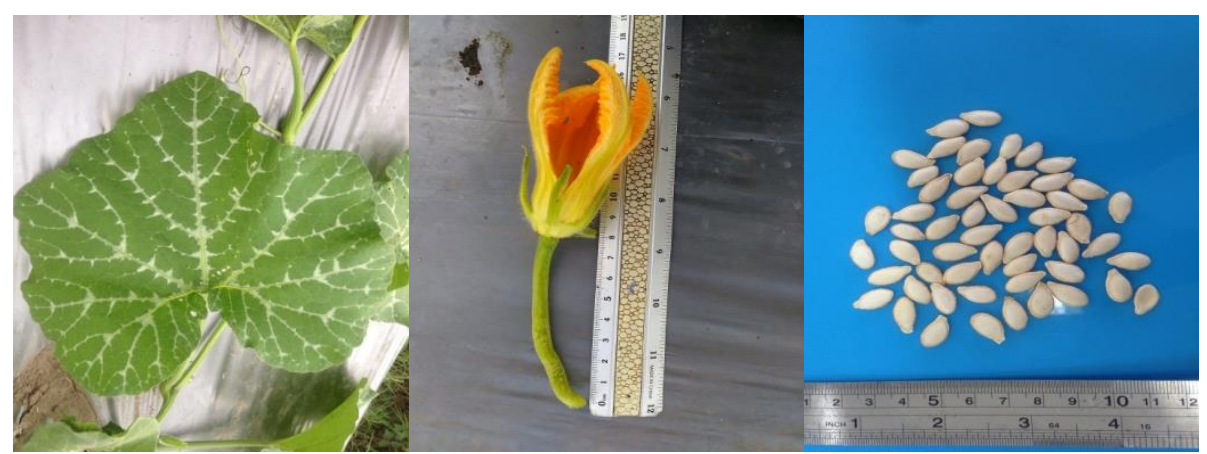

$\mathrm{D}$

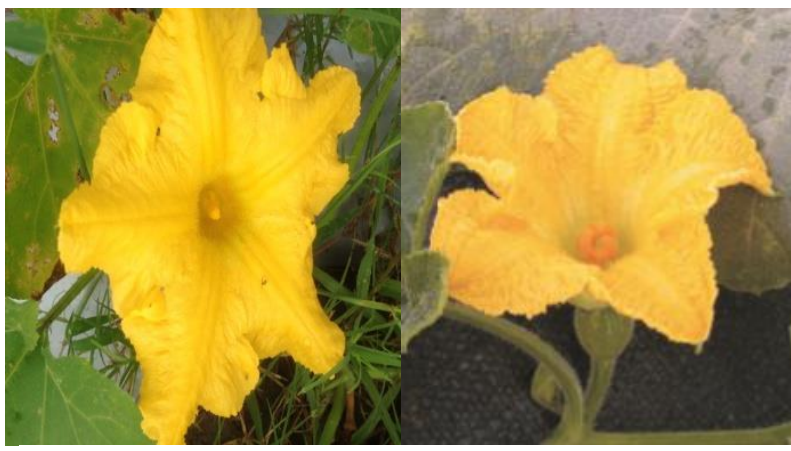

G
$\mathrm{E}$

$\mathrm{H}$
F

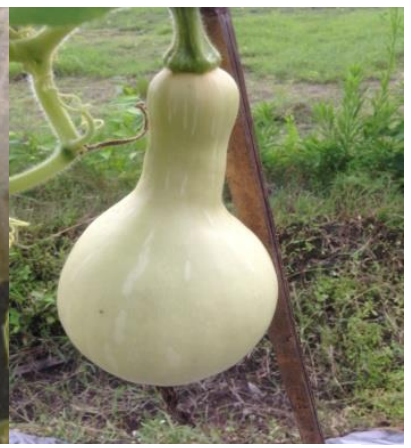

I

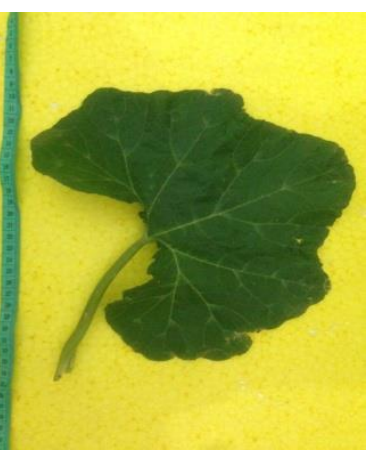

C

Gambar 2. Karakter fenotip tanaman labu susu: A. akar, B. batang, C. helaian dan tangkai daun, D. pertulangan daun, E. tangkai bunga, F. biji, G. bunga jantan, H. bunga hemafrodit, dan I. buah muda

Berdasarkan penelitian yang telah dilakukan, diperoleh hasil karakterisasi fenotip tanaman labu susu secara kuantitatif (Tabel 1) dan analisis produktivitas (Gambar 3) sebagai berikut:

Tabel 1. Uji kestabilan fenotip tanaman labu susu secara kuantitatif (One Way ANOVA)

\begin{tabular}{|c|c|c|c|c|}
\hline \multirow[b]{2}{*}{ No. } & \multirow[b]{2}{*}{ Karakter Fenotip } & \multicolumn{3}{|c|}{ Rerata } \\
\hline & & $\begin{array}{l}\text { G1 }_{1} \text { Screen House } \\
\text { PIAT UGM }\end{array}$ & $\begin{array}{c}\text { G2 }_{2} \text { Lahan PIAT } \\
\text { UGM }\end{array}$ & $\begin{array}{c}\text { G3 Screen House } \\
\text { Jamusan }\end{array}$ \\
\hline 1 & Tinggi Batang (m) & $5,21 \pm 0,62^{b}$ & $4,45 \pm 0,80^{\mathrm{a}}$ & $4,45 \pm 0,80^{\mathrm{a}}$ \\
\hline 2 & Keliling Batang (cm) & $5,40 \pm 0,61^{b}$ & $4,30 \pm 0,67^{\mathrm{a}}$ & $4,50 \pm 0,85^{\mathrm{a}}$ \\
\hline 3 & Lebar Daun $(\mathrm{cm})$ & $27,84 \pm 0,71^{b}$ & $25,80 \pm 0,55^{\mathrm{a}}$ & $26,12 \pm 0,75^{\mathrm{a}}$ \\
\hline 4 & Panjang Daun $(\mathrm{cm})$ & $19,00 \pm 0,97^{b}$ & $18,10 \pm 0,91^{\mathrm{a}}$ & $18,50 \pm 0,82^{\mathrm{a}}$ \\
\hline 5 & Panjang Tangkai Daun (cm) & $18,99 \pm 0,82^{b}$ & $15,92 \pm 0,74^{\mathrm{a}}$ & $15,82 \pm 0,72^{\mathrm{a}}$ \\
\hline 6 & Diameter Tangkai Daun (cm) & $1,35 \pm 0,24^{\mathrm{a}}$ & $1,20 \pm 0,26^{\mathrm{a}}$ & $1,35 \pm 0,24^{\mathrm{a}}$ \\
\hline 7 & Panjang Tangkai Bunga Jantan $(\mathrm{cm})$ & $8,90 \pm 0,99^{b}$ & $7,50 \pm 0,85^{\mathrm{a}}$ & $7,58 \pm 0,75^{\mathrm{a}}$ \\
\hline 8 & Panjang Tangkai Bunga Hemafrodit $(\mathrm{cm})$ & $3,15 \pm 0,53^{\mathrm{a}}$ & $3,10 \pm 0,32^{\mathrm{a}}$ & $3,25 \pm 0,35^{\mathrm{a}}$ \\
\hline 9 & Panjang Kelopak Bunga Jantan (cm) & $2,67 \pm 0,47^{\mathrm{a}}$ & $2,64 \pm 0,46^{\mathrm{a}}$ & $2,60 \pm 0,52^{\mathrm{a}}$ \\
\hline
\end{tabular}




\begin{tabular}{llcrc}
\hline $\mathbf{1 0}$ & $\begin{array}{l}\text { Panjang Kelopak Bunga Hemafrodit } \\
(\mathrm{cm})\end{array}$ & $3,70 \pm 0,67^{\mathrm{a}}$ & $3,68 \pm 0,48^{\mathrm{a}}$ & $3,71 \pm 0,49^{\mathrm{a}}$ \\
\hline $\mathbf{1 1}$ & Panjang Mahkota Bunga Jantan $(\mathrm{cm})$ & $8,05 \pm 0,86^{\mathrm{a}}$ & $8,03 \pm 0,71^{\mathrm{a}}$ & $8,10 \pm 0,66^{\mathrm{a}}$ \\
\hline $\mathbf{1 2}$ & $\begin{array}{l}\text { Panjang Mahkota Bunga Hemafrodit } \\
(\mathrm{cm})\end{array}$ & $8,90 \pm 0,56^{\mathrm{a}}$ & $8,87 \pm 0,52^{\mathrm{a}}$ & $8,89 \pm 0,38^{\mathrm{a}}$ \\
\hline $\mathbf{1 3}$ & Berat Buah (kg) & $1,26 \pm 0,63^{\mathrm{a}}$ & $1,042 \pm 0,24^{\mathrm{a}}$ & $1,04 \pm 0,24^{\mathrm{a}}$ \\
\hline $\mathbf{1 4}$ & Keliling Buah (cm) & $24,83 \pm 4,54^{\mathrm{a}}$ & $27,13 \pm 2,65^{\mathrm{a}}$ & $27,13 \pm 2,65^{\mathrm{a}}$ \\
\hline $\mathbf{1 5}$ & Panjang Buah (cm) & $27,60 \pm 4,42^{\mathrm{a}}$ & $24,46 \pm 3,88^{\mathrm{a}}$ & $24,46 \pm 3,88^{\mathrm{a}}$ \\
\hline $\mathbf{1 6}$ & Tebal Kulit Buah (cm) & $0,35 \pm 0,11^{\mathrm{b}}$ & $0,22 \pm 0,06^{\mathrm{a}}$ & $0,24 \pm 0,07^{\mathrm{a}}$ \\
\hline $\mathbf{1 7}$ & Tebal Daging Buah (cm) & $2,95 \pm 0,28^{\mathrm{a}}$ & $3,34 \pm 0,31^{\mathrm{b}}$ & $3,36 \pm 0,34^{\mathrm{b}}$ \\
\hline $\mathbf{1 8}$ & Panjang Biji (cm) & $1,47 \pm 0,05^{\mathrm{a}}$ & $1,49 \pm 0,06^{\mathrm{a}}$ & $1,51 \pm 0,06^{\mathrm{a}}$ \\
\hline $\mathbf{1 9}$ & Lebar Biji (cm) & $0,82 \pm 0,06^{\mathrm{a}}$ & $0,8 \pm 0,05^{\mathrm{a}}$ & $0,81 \pm 0,07^{\mathrm{a}}$ \\
\hline $\mathbf{2 0}$ & Berat Basah Biji (gram) & $101,15 \pm 0,88^{\mathrm{a}}$ & $100,58 \pm 0,90^{\mathrm{a}}$ & $100,57 \pm 0,86^{\mathrm{a}}$ \\
\hline $\mathbf{2 1}$ & Berat Kering Biji (gram) & $11,06 \pm 0,72^{\mathrm{a}}$ & $11,02 \pm 0,74^{\mathrm{a}}$ & $10,99 \pm 0,71^{\mathrm{a}}$ \\
\hline
\end{tabular}

Ket: Data ditampilkan dengan nilai rerata \pm standar deviasi. Angka yang diikuti oleh huruf yang sama pada baris yang sama menunjukkan hasil yang tidak berbeda nyata pada uji Duncan taraf $5 \%$.

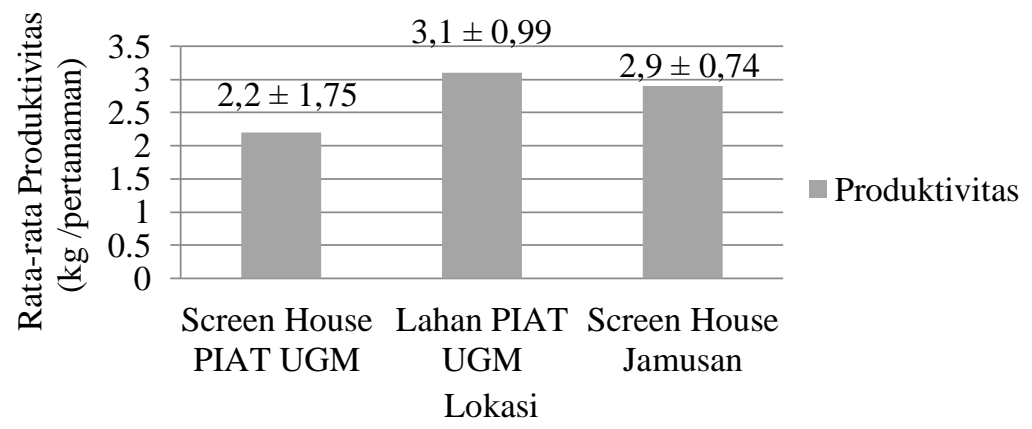

Gambar 3. Histogram produktivitas tanaman labu hasil budidaya di screen house PIAT UGM, lahan PIAT UGM, dan screen house Jamusan

\section{PEMBAHASAN}

Teknologi pemuliaan tanaman (plant breeding) merupakan suatu usaha untuk memperoleh produk varietas unggul melalui metode persilangan dan pemanfaatan teknologi pertanian yang intensif seperti halnya pemuliaan tanaman labu susu (Daryono dan Maryanto, 2017). Pemuliaan tanaman dengan metode persilangan menghasilkan tanaman hibrid yang sifatnya tidak identik dengan induknya dan saat perbanyakan tanaman sering mengalami segregasi. Hal ini tidak baik untuk produksi benih sehingga perlu dilakukan pemurnian galur untuk menghasilkan benih tanaman labu susu yang stabil terhadap berbagai kondisi lingkungan dan memiliki tingkat produktivitas yang lebih tinggi. Pada penelitian ini dilakukan penggaluran untuk mendapatkan indukan dan keturunan tanaman labu susu dengan bentuk buah pir/dumbbell.

Dalam pemuliaan tanaman juga diperlukan serangkaian uji untuk mendapatkan varietas tanaman yang unggul, berdaya saing tinggi, dan mampu beradaptasi dengan baik terhadap lingkungan. Pengujian yang dilakukan dalam pemuliaan tanaman antara lain uji multilokasi, uji multimusim, dan uji pengulangan. Pada penelitian ini dilakukan uji kestabilan fenotip tanaman labu susu secara kualitatif dan kuantitatif di tiga lokasi yang berbeda yaitu screen house PIAT UGM, lahan PIAT UGM, dan screen house Jamusan, Bokoharjo. Ketiga lokasi tersebut berada di daerah dataran rendah dengan ketinggian \pm 200 mdpl, tanah berpasir dan subur, serta termasuk daerah persawahan yang memiliki suhu sedang $\left(32-33^{\circ} \mathrm{C}\right)$.

Penanaman dilakukan pada tiga lokasi yang berbeda dengan kondisi musim kemarau dan penghujan untuk menguji pertumbuhan dan kestabilan fenotip tanaman labu susu pada kondisi lingkungan yang bervariasi. Karakter fenotip merupakan sifat yang tampak dari luar suatu individu, dapat diamati dan diukur sebagai hasil dari genotip dan lingkungannya. 
Fenotip pada suatu organisme ditentukan olek interaksi protein-protein yang terdapat di dalam sel. Protein-protein tersebut merupakan kumpulan asam amino dengan urutan tertentu yang pembentukannya dikode oleh suatu gen (Daryono dan Nofriarno, 2018). Pengamatan fenotip dapat dilakukan berdasarkan sifat kuantitatif dan kualitatif. Berdasarkan uji kestabilan fenotip labu susu secara kualitatif (Gambar 1) di atas diketahui bahwa tanaman labu susu memiliki 3 bentuk yang berbeda yaitu bentuk buah pir atau paprika yang termasuk bentuk dumbbell dan bentuk leher angsa (pyriform). Adanya perbedaan tersebut dipengaruhi oleh faktor internal yaitu gen, mekanisme transpor dan translokasi ion serta faktor eksternal seperti faktor iklim (curah hujan, suhu, kelembaban udara, dan intensitas cahaya matahari), faktor tanah (jenis tanah, kesuburan, ketinggian), pemupukan, dan umur panen buah.

Pada tanaman labu susu dijumpai memiliki buah berbentuk paprika dan pir dalam satu tanaman. Hal tersebut mengindikasikan bahwa bentuk paprika hanya bersifat plastis dan merupakan hasil dari perbedaan transport unsur hara dan translokasi fotosintat akibat pengaruh lingkungan. Buah berbentuk leher angsa merupakan hasil segregasi gen dan diwariskan kepada turunannya karena terletak pada tanaman yang berbeda. Pembentukan gamet terjadi secara meiosis ketika pasangan-pasangan homolog saling berpisah dan tidak berpasangan lagi atau terjadi pemisahan alel (Brown and Myers, 2002). Dengan demikian, setiap sel gamet pada tanaman labu susu hanya mengandung satu gen dari alelnya. Pada saat pembentukan gamet indukan tanaman labu susu baik jantan atau hemafrodit hanya mengandung satu macam alel yang baik berupa alel dominan atau pun alel resesif kemudian pada saat terjadi fase reproduksi generatif kedua gamet akan menyatu dan membentuk karakter genotip baru pada anakan tanaman labu susu yang pada hal ini berupa pengekspresian karakter fenotip resesif bentuk buah pyriform. Tanaman labu susu dapat mengekspresikan gen bentuk buah dumbbell secara maksimal dan mengaktifkan gen bentuk buah pyriform akibat pengaruh faktor lingkungan sehingga terjadi kombinasi pengekspresian fenotip yang berbeda antar generasi.

Berdasarkan karakter fenotip kualitatif (Gambar 1) diatas dapat diketahui bahwa tanaman labu susu belum stabil terhadap variabilitas lingkungan yang berbeda dan cara tanam yang tidak terlalu intensif. Hal tersebut ditunjukkan dengan adanya perbedaan bentuk buah tanaman indukan dan keturunan yang signifikan.

Tanaman labu susu (Gambar 2) memiliki batang yang berbentuk bersegi 5 tumpul yang tumbuh merambat dan dilengkapi dengan sulur berpilin (spiral) yang muncul pada ketiak daun. Daun labu susu adalah daun tunggal dengan kedudukan tersebar, memiliki tangkai daun dengan ukuran panjang kurang lebih sama dengan panjang helaian daun. Tangkai daun berbentuk segi lima dan berambut di permukaannya. Helaian daun berbentuk jantung dan memiliki pertulangan daun menjari dengan 3 tulang lateral. Permukaan daun dilengkapi oleh trikoma berbentuk jarum (Purnomo et al., 2015). Tanaman labu susu memiliki akar tunggang berwarna putihcokelat dengan radius $30-50 \mathrm{~cm}$.

Bunga labu susu merupakan tanaman andromonoecious yaitu pada satu tanaman terdapat bunga jantan dan bunga hemafrodit yang menjadi penciri tanaman modern karena lebih efisien dalam melakukan penyerbukan (Robinson, 2000). Bunga memiliki 5 daun kelopak dan 5 daun mahkota yang saling berlekatan. Bunga jantan terletak di ketiak daun (flos axillaris) dan memiliki tangkai bunga yang lebih panjang daripada bunga hemafrodit. Bunga jantan memiliki benang sari berwarna kuning tua sedangkan pada hemafrodit memiliki benang sari berwarna jingga dengan putik berwarna hijau. Stamen bersifat syanthera yaitu alat kelamin jantan sebanyak 5 bersatu pada kepalanya. Kepala putik berjumlah 3 dengan letak bakal buah tenggelam dan bakal buah bersifat sinkarp karena jumlah ruang sesuai dengan jumlah daun buah. Plasentasi bakal buah labu susu terdapat pada sudut tengah pertemuan dari daun-daun buah yang disebut axillaris (Purnomo et al., 2015). Bunga tanaman labu 
susu mekar pada saat pagi hari sekitar pukul 05.30-10.00 WIB.

Buah labu susu memiliki tekstur renyah, kulit buah berwarna pale yellow (RHS greyed orange group 65), warna daging buah strong orange (RHS orange group 24), tingkat kemanisan $3-5^{\circ}$ brix dengan aroma menyengat dan daya simpan yang lama mencapai 6-12 bulan. Biji labu susu memiliki bentuk konstan dengan bentuk pipih, bulat telur (oval) dengan ujung membulat. Permukaan biji licin mengkilap dengan jumlah biji 18-169 di setiap buah dan tingkat viabilitas $80-90 \%$.

Berdasarkan hasil penelitian, tanaman labu susu hasil galur murni di screen house PIAT UGM, lahan PIAT UGM, dan screen house Jamusan sama-sama memiliki bentuk dan warna akar, batang, daun, bunga, dan biji yang sama, akan tetapi terdapat perbedaan pada bentuk buah setiap tanaman (Gambar 1). Berdasarkan Tabel 1 menunjukkan bahwa karakter fenotip kuantitatif tanaman labu susu hasil budidaya di screen house PIAT UGM, lahan PIAT UGM, dan screen house Jamusan tidak berbeda nyata untuk diameter tangkai daun, panjang tangkai bunga hemafrodit, panjang kelopak bunga jantan dan hemafrodit, panjang mahkota bunga jantan dan hemafrodit, berat buah, keliling buah, panjang buah, lebar biji, panjang biji, berat basah biji, dan berat kering biji. Karakter fenotip tinggi batang, keliling daun, lebar daun, panjang daun, panjang tangkai daun, panjang tangkai bunga jantan, tebal kulit buah, dan tebal daging buah labu susu berbeda nyata untuk hasil budidaya di screen house PIAT UGM dengan lahan PIAT UGM dan screen house Jamusan pada taraf signifikansi 5\%. Hal ini menunjukkan bahwa pada tingkat kepercayaan 95\% tanaman labu susu memiliki karakter fenotip kuantitatif yang seragam tetapi belum stabil.

Labu susu hasil budidaya di lahan PIAT UGM memiliki produktivitas yang lebih besar yaitu $3,1 \pm 0,99$ buah per tanaman dibandingkan produktivitas buah labu susu yang ditanam di screen house PIAT UGM dan Jamusan (Gambar 3). Hal ini dikarenakan tanaman labu susu di lahan mendapatkan sinar matahari secara langsung sehingga dapat melakukan fotosintesis dan akumulasi amilum lebih optimal.

Intensitas cahaya yang rendah pada screen house disebabkan terhambatnya radiasi sinar matahari oleh dinding pembatas. Hal ini mengakibatkan tidak terjadinya fotorespirasi pada tanaman labu sehinga energi yang dihasilkan hanya digunakan untuk proses fotosintesis untuk menaikkan produktivitas. Tanaman labu susu pada screen house memiliki karakter morfologi daun yang lebih lebar dengan warna hijau sebagai adaptasi terhadap kondisi ternaungi. Berdasarkan pengaruh faktor lingkungan penelitian, dapat diketahui bahwa tanaman labu susu masih toleran terhadap variabilitas lingkungan (suhu $32-33^{\circ} \mathrm{C}$ dan kelembaban tanah kering) dengan mempertahankan daya produktivitas yang dinilai masih optimum (3-4 buah per tanaman).

\section{KESIMPULAN}

Berdasarkan hasil penelitian, dapat disimpulkan bahwa labu susu hasil budidaya di screen house PIAT UGM, lahan PIAT UGM, dan screen house Jamusan memiliki karakter fenotip yang seragam meskipun belum stabil yang ditunjukkan dengan perbedaan bentuk buah dan ukuran tanaman. Labu susu memiliki 3 bentuk yang berbeda yaitu bentuk buah pir atau paprika yang termasuk bentuk dumbbell dan bentuk leher angsa (pyriform), tekstur renyah, kulit buah berwarna Pale Yellow (RHS Greyed Orange Group 65), warna daging buah strong orange (RHS orange group 24), tingkat kemanisan $3-5^{\circ}$ brix, daya simpan lama, dan umur panen yang singkat (70-90 HST). Labu susu hasil budidaya di lahan PIAT UGM memiliki produktivitas yang lebih besar yaitu $3,1 \pm 0,99 \mathrm{~kg}$ per tanaman.

\section{UCAPAN TERIMA KASIH}

Penelitian ini merupakan bagian dari Hibah Penelitian Kolaborasi Dosen dan Mahasiwa Dana BPPTNbh Fakultas Biologi UGM Tahun 2018. Penulis mengucapkan terima kasih kepada Bapak Romli, Gama Melon, dan Fakultas Biologi UGM atas bantuan serta kerjasamanya dalam budidaya labu susu di Sleman, Yogyakarta. 


\section{DAFTAR PUSTAKA}

Babadoost M, and Zitter TA. 2009. Fruit Rots of Pumpkin A Serious threat to the Pumpkin Industry. Plant Disease. vol 93(8): $772-782$. https://doi.org/10.1094/PDIS-93-8-0772.

Bisognin DA. 2002. Origin and evolution of cultivated cucurbits. Ciência Rural. vol 32(4):

715-723. https://doi.org/10.1590/S010384782002000400028.

Brown RN, and Myers JR. 2002. A Genetic Map of Squash (Cucurbita sp.) with Randomly Amplified Polymorphic DNA Markers and Morphological Markers. Journal of the American Society for Horticultural Science. vol 127(4): 568575.

Daryono BS, dan Maryanto SD. 2017. Keanekaragaman dan Potensi Sumber Daya Genetik Melon. Yogyakarta: Gadjah Mada University Press.

Daryono B., dan Nofriarno N. 2018. Pewarisan Karakter Fenotip Melon (Cucumis melo L. 'Hikapel Aromatis') Hasil Persilangan $\rightarrow$ 'Hikapel' dengan $\hat{\sigma}$ 'Hikadi Aromatik.' Biosfera. vol 35(1): 44-48. https://doi.org/https://doi.org/10.20884/1 .mib.2018.35.1.586.

Ferriol M, Picó B, De Córdova PF, Nuez F. 2004. Molecular diversity of a germplasm collection of squash (Cucurbita moschata) determined by SRAP and AFLP markers. Crop Science. vol 44(2): 653-664.

https://doi.org/10.2135/cropsci2004.653 0.

Hazra P, Mandal AK, Dutta AK, Ram HH. 2007. Breeding Pumpkin (Curcubita moschata (Duch. Ex Poir.) for Fruit Yield and Other Character. International Journal of Plant Breeding. vol 1(1): 5164.

Hendrasty HK. 2003. Teknologi Pengolahan Pangan: Tepung Labu Kuning. Yogyakarta: Kanisius.

Human S, Loekito S, Trilaksono M, Syaifudin A. 2016. Pemuliaan Mutasi Tanaman Nanas (Ananas comusus (L.) Merr.) Menggunakan Iradiasi Gamma untuk
Perbaikan Varietas Nanas Smooth Cayenne. Jurnal Ilmiah Aplikasi Isotop Dan Radiasi. vol 12(1): 13-18. https://doi.org/http://dx.doi.org/10.17146 /jair.2016.12.1.3197.

Inan N, Yildiz M, Sensoy S, Kafkas S, Abak K. 2012. Efficacy of ISSR and SRAP techniques for molecular characterization of some cucurbita genotypes including naked (hull-less) seed pumpkin. Journal of Animal and Plant Sciences. vol 22(1): 126-136.

https://doi.org/10.1109/TAC.2010.20405 12.

Muzzaffar S, Baba WN, Nazir N, Masoodi F. A, Bhat MM, Bazaz R. 2016. Effect of storage on physicochemical, microbial and antioxidant properties of pumpkin (Cucurbita moschata) candy. Cogent Food \& Agriculture. vol 2: 1-13. https://doi.org/10.1080/23311932.2016.1 163650.

Paris HS, Brown RN. 2005. The genes of pumpkin and squash. HortScience. vol 40(6): $1620-1630$. https://doi.org/10.1007/s12374-0120377-3.

Purnomo, Daryono BS, Sentori MB. 2015. Variability and Intraspecies Classification of Pumpkin (Curcubita moschata (Duch. Ex Lam.) Duch. Ex Poir.) Based on Morphological Characters. International Conference on Biological Sciences, KnE Life Science. vol 2: 286-293. https://doi.org/http://dx.doi.org/10.18502 /kls.v2i1.160.

Ramadhani F, Putri LAP, Hasyim H. 2013. Evaluasi Karakteristik Beberapa Varietas Kedelai (Glycine max L.merill) Hasil Mutasi Kolkisin M2 Pada Kondisi Naungan. Jurnal Online Agroekoteknologi. vol 1(3): 453-466.

Riaz S, Malook S, Shah AH, Sarfaraz M, Kazmi SMZ, Abad Z, Jabee S, Zaman RQU, Asif M, Ali Q. 2015. Improvement of secondary metabolites for Cucurbita moschata through tissue culture techniques: An overview. Life Science Journal. vol 12(4): 94-101. 
Robinson R. 2000. Rationale and methods for producing hybrid cucurbit seed. Journal of New Seeds. vol 1(3-4): 1-47. https://doi.org/10.1300/J153v01n03.

Šiško M, Ivančič A, Bohanec B. 2003. Genome size analysis in the genus Cucurbita and its use for determination of interspecific hybrids obtained using the embryorescue technique. Plant Science. vol 165(3): 663-669. https://doi.org/10.1016/S01689452(03)00256-5.

Suwanto, Suranto, Purwanto E. 2015. Karakterisasi Labu Kuning (Curcubita moschata Duch. ) pada Lima Kabupaten di Provinsi Jawa Timur. El-Vivo. vol 3(1):
61-71.

Tedianto. 2012. Karakterisasi Labu Kuning (Cucurbita Moschata) Berdasarkan Penanda Morfologi dan Kandungan Protein, Karbohidrat, Lemak Pada Berbagai Ketinggian Tempat [Tesis]. Surakarta: Universitas Sebelas Maret.

Wu J, Chang Z, Wu Q, Zhan H, Xie S. 2011. Molecular diversity of Chinese Cucurbita moschata germplasm collections detected by AFLP markers. Scientia Horticulturae. vol 128(1): 7-13. https://doi.org/10.1016/j.scienta.2010.12. 006. 